\title{
Business History, the Great Divergence and the Great Convergence
}

\section{Citation}

Jones, Geoffrey. "Business History, the Great Divergence and the Great Convergence." Harvard Business School Working Paper, No. 18-004, July 2017.

\section{Permanent link}

http://nrs.harvard.edu/urn-3:HUL.InstRepos:33840636

\section{Terms of Use}

This article was downloaded from Harvard University's DASH repository, and is made available under the terms and conditions applicable to Open Access Policy Articles, as set forth at http:// nrs.harvard.edu/urn-3:HUL.InstRepos:dash.current.terms-of-use\#OAP

\section{Share Your Story}

The Harvard community has made this article openly available.

Please share how this access benefits you. Submit a story. 


$$
\text { H A R VAR D B US INESS SCHOOL }
$$

\section{Business History, the Great Divergence and the Great Convergence}

Geoffrey Jones

Working Paper 18-004 


\section{Business History, the Great Divergence and the Great Convergence}

Geoffrey Jones

Harvard Business School

Working Paper 18-004 


\title{
Business History, the Great Divergence and the Great Convergence
}

\section{Geoffrey Jones}

\begin{abstract}
This working paper provides a business history perspective on debates about the Great Divergence, the rise of the gap in incomes between the West and the Rest, and the more recent Great Convergence, which has seen a narrowing of that gap. The literature on the timing and causes of the Great Divergence has focussed on macro analysis. This working paper identifies the potential for more engagement at the micro level of business enterprises. While recognizing that the context of institutions, education and culture play a role in explanations of wealth and poverty, the paper calls for a closer engagement with the processes how these factors translated into generating productive firms and entrepreneurs. The challenges of catching-up were sufficiently great in the Rest that initially minorities held significant advantages in capital-raising and trust levels which enabled them to flourish as entrepreneurs. Yet by the interwar years there is evidence of more general emergence of modern business enterprise in Asia, Latin America and Africa. Many governmental policies after 1945 designed to facilitate catch-up ended up crippling such emergent business enterprises without putting effective alternatives in place. The second wave of globalization from the 1980s provided more opportunities for catch up from the Rest. Firms from emerging markets had the opportunity to access the global networks which replaced large integrated firms. There were also new ways to access knowledge and capital, including through management consultancies and hiring graduates from business schools. The upshot was the rise to global prominence of firms based in the Rest, including Foxcomm, Huawei, HNA, Cemex, and TCS.
\end{abstract}




\section{Introduction}

Over the last decade the Great Divergence, or the timing of when the wealth gap between the Western world and the Rest of the world opened up, has been prominent issue in the discipline of economic history. The debate has been conducted at a macro-economic level, however, and business historians have made hardly any contribution. They have made a potentially richer contribution to the less explored question why the Rest failed to catch up after the gap had opened up, though most of this literature has not been structured in terms of the Great Divergence. This working paper begins with these two debates before turning to the Great Convergence of the last three decades. By 2017 China was the world’s second largest economy. It accounted for nearly 15 per cent of world GDP. Asia as a whole accounted for 34 per cent of world GDP; the United States and Canada for 28 per cent; and Europe for only 21 per cent (World Economic Forum, 2017). While many developing economies, especially in Africa, were still desperately poor compared to the West, the scale and speed of the Great Convergence was nevertheless striking.

\section{The Great Divergence}

Although the data is highly contested, most economic historians would agree that the large inequality which became evident in the nineteenth century between regions is relatively "new," at least in historical terms. The timing, however, remains contentious. A consensus that incomes had diverged between Europe and China in the early modern period was disrupted around 2000 when Pomeranz put the term "the Great Divergence” into scholarly usage by suggesting that certain regions of China, India, and Western Europe were at broadly similar levels of agricultural productivity, commercial development and the ability of some firms to raise capital in the middle of the eighteenth 
century. The Great Divergence in wealth between the West and the Rest, then, began with the Industrial Revolution and the advent of modern economic growth in Britain (Pomeranz, 2000).

The Pomeranz hypothesis provoked a surge of quantitative research on comparative income levels. Research has focused on two indices - GDP per capita and real wage levels. This research has mostly concluded suggested that income levels between Europe and Asia were already wide in the eighteenth century, reflecting trends which began at least three hundred years earlier. It suggests that the real income gap was between the most advanced countries in Europe - Britain, the Netherlands and Belgium - and other regions, whether China, India or central and southern Europe. What happened during the nineteenth century was that much more of the West caught up to the advanced North Sea countries, but the Rest did not (Broadberry and Gupta, 2006:Van Zanden, 2009; Allen et al 2011; Li and Van Zanden, 2012).

A major critique of this entire literature is that historical Chinese data simply does not support the use being made of it to derive these statistics. Deng and O’Brien have written extensively why available data in China cannot be compared to that available in western countries such as Britain and the Netherlands. Their own estimates, using an entirely different approach, suggests that China may have been falling behind the West from the early seventeenth century, but their primary achievement has been to cast doubt on what was becoming a consensus in economic history - that the Great Divergence really did start in the early modern period. (Deng and O’Brien, 2015, 2016a, 2016B, 2017).

A striking feature of the Great Divergence debate, beyond the shaky data on which it rests, is that it has been, as Zan and Deng put it, "conducted at the macro-level, i.e. 
macro regions (e.g. the Yangtze Delta and Western Europe), macro sectors (e.g. technology, services, industry, farming, and governance), and macro issues (e.g. growth, development, living standards.” (Zan and Deng, 2017). Yet the same study showed the potential for a business history approach. The authors point to improved management accounting methods which appeared in early modern Europe, especially sixteenth century Venice, and the lack of any equivalent in China. They speculate that this may be due not back luck that archives were not preserved, but rather a reflection of different attitudes towards finance and money than in the West. (Zan and Deng, 2017) Business historians have a real opportunity to engage in the Great Divergence debate by investigating managerial practices and systems in the early modern period.

\section{The Failure to Catch Up}

A much less explored question, and one to which business historians have more to contribute, is why after the Great Divergence had happened, it took the Rest so long to catch up. More particularly, while many regions of Europe caught up with the home of modern industrialization around the North Sea, it took the Rest of the world much longer. Bénétrix, O’Rourke and Williamson (2015) have shown that from the late nineteenth century, the "periphery" began to follow the path of industrialization set in the West. Some Latin American countries began such “convergence” from the 1870s, followed by some Asian countries after 1890, followed again by parts of sub-Saharan Africa and the Middle East during the interwar years. Yet the emergence and growth of modern industrial sectors was not sufficient to close the substantial income gaps which had opened. This was primarily because dynamic and innovative firms were slow to emerge from these regions. 
Most of the existing explanations for the slowness of catch-up have been at the macro-level, and have only implicitly explained the lack of emergence of modern firms. These explanations can be crudely summarized as falling into three buckets. The first, and initial, explanatory bucket is the role of culture. The West had the "right" culture, and the rest had "wrong” cultures for capitalist enterprise. Writers from Weber (2011 edit) to Landes (1998) to Mokyr (1990, chapter 9) have made this argument, as has more recently Ferguson when he identified the Protestant work ethic as one of the West's "killer apps." (Ferguson, 2011) However leaving aside the well-known criticisms of such cultural generalizations, these studies have never explained how exactly culture impacts firm formation and quality of business decision-making.

The second big explanation is that, following the work of North, the West had the "right” institutions to promote capitalist economic growth, and the Rest did not. (North 1990, 2005). This has led to debates about the long-term impact of particular colonial regimes, such North America had the "right" sort of colonialism, while the Rest did not, and about countries with common law having the "right" legal regime for encouraging capitalist development, and the rest not. A big problem is that this literature has largely used property rights laws as a proxy for institutions. (Jones 2013, 14-18). It is not evident that the West had superior property rights regimes to parts of the Rest. British India has the common law system. The widespread existence of market activities and the importance of private property in nineteenth century (and earlier) China would not suggest an overwhelmingly poor property rights regime. (Faure 2006, Deng 2000). While the lack of company law in that country might have made capital-raising hard, when China finally 
introduced a Company Law Act enabling limited liability in 1904, few Chinese companies registered under the act. (Kirby 1995)

Nor is it evident that business enterprises were simply passive recipients of legal regimes. Musacchio has raised serious doubts concerning the adverse impact of civil law regimes on financial and economic development. Brazil was a French civil law country with apparently inadequate creditor protection and contract enforcement, but Musacchio found that Brazilian firms used their own byelaws to offer strong protection for equity investors. (Musacchio, 2008)

Finally, education (or lack of it) has been used as an explanatory factor for global wealth and poverty (Easterlin, 1981). Goldin (2001) has made a strong case for attributing American industrial leadership to the unique egalitarian mass provision of post elementary schooling achieved in the United States during the early twentieth century. While plausible, the link with the development of modern business has never been clearly established. Worryingly, eighteen and nineteenth century China had widespread literacy, which did not translate into the creation of modern firms. (Deng 2000) Probably the greatest negative consequence of low education levels was raising the cost of skilled labor. In the case of colonial India, the high cost of skilled labor has been identified as one possible explanation why the country remained inclined to small-scale traditional manufacture. (Roy 2000, chapter 7)

Context - whether institutional, cultural, or education - matters for capitalist development, but the existing Great Divergence literature, primarily written by economists, has yet to provide firm evidence how exactly it shaped entrepreneurship and business. Baumol's work on differences in what he terms the rules of the game between society 
enables a more explicit connection to be built. Baumol argued that the contribution of entrepreneurship on societies varied because of the allocation between productive activities such as innovation and unproductive activities such as rent seeking or organized crime. This allocation, Baumol suggested, was in turn influenced by the relative pay offs offered by a society to such activities. (Baumol 1990)

Maurer's study of the Mexican financial system from the late nineteenth century shows how this context played out in one country by demonstrating how the existence of an undemocratic political system and selective enforcement of property rights shaped the financial and business system. Limited in its ability to raise taxes to finance infrastructure projects as well as fend off political opponents, the Mexican government of the dictator Porfirio Diaz relied on banks to provide credit, while the banks relied on the government to enforce property rights. A select few bankers were given extensive privileges producing a highly concentrated banking system. Each bank grew fat in its own protected niche. To overcome the problems associated with information asymmetry, banks lent to their own shareholders and other insiders. In the case of the textile industry, banks did not lend to the best firms, but the best-connected firms. Poorly defined property rights prevented those excluded from the insider networks from pledging collateral and finding another financial route. (Maurer 2002)

More broadly, institutional and societal context was a major factor explaining why technological catch-up was a huge entrepreneurial challenge for entrepreneurs in nineteenth century India, Mexico and elsewhere in the Rest. The new advanced technologies of the West were embedded in quite different (not better or worse) institutional, economic and social contexts than in the Rest. Entrepreneurs could not 
simply import them and they would work. Factor endowments fundamentally shaped the commercial viability of different transferred technologies.(Roy 2009) Relevant technologies needed to be identified, they need to be adapted, they needed to be financed, and they needed to be used. This was challenging and costly, although not impossible. (Beatty 2003a and 2003b) This explains, in part, why there were such significant regional differences in entrepreneurial performance in many nineteenth century Latin American countries, despite having the same laws, language and culture at the national level. (Cerutti, 1996)

Closer examination of the "institutional arrangements" which promoted growth in many countries raise many questions about the "right" and "wrong" institutions which promoted entrepreneurship and firm growth. For example, the historical evidence does not support the argument that the protection of intellectual property rights and patents was important to promoting entrepreneurship from an institutional perspective. The evidence that patents in Britain played an important role in the Industrial Revolution and later is weak. The cost of obtaining a patent in eighteenth century Britain was high, and they were difficult to enforce. (Mokyr 2009) Moser showed that, historically, that in countries with patent laws the majority of innovations have occurred outside of the patent system, while conversely countries without patent laws produced as many innovations as countries with patent laws during the same time periods, and their innovations were of comparable quality. (Moser 2013)

The role of colonialism poses a particular challenge to institutional explanations of variations in the allocation of entrepreneurial energy. Most economics research on the impact of colonialism on the Great Divergence focusses on the highly exploitative first 
stages of European colonialism, especially in Latin America. However the policy regime of empires changed over time. While traditional Indian handicraft industries suffered from British free trade policies in the nineteenth century, during the interwar decades British India was protectionist, including against British imports. (Morris 1983). The British brought not only political stability to nineteenth century India, after decades of turbulence. but also their legal system with protection of property rights and contract enforcement. The British administrators in India simplified and codified British laws in ways which appear to have made them even more enterprise-friendly.

Yet when investments began in large-scale industry from the mid-nineteenth century, they were highly clustered geographically and ethnically. Scotsmen developed the modern jute industry of Calcutta from the 1860s, whilst the tiny ethnic minority of Parsees developed the textile industries on the west coast. Modern indigenous entrepreneurship became, and has remained, highly concentrated ethnically. Subsequently Marwaris, originating from Rajasthan, and the Vanias from Gujerat joined the Parsees as the dominant entrepreneurial groups, a situation which lasted until the early twenty first century (Tripathi 2004: Markovits, 2008)

Market size might be important. The growth and size of the American market provides a key component of the Chandlerian explanation for the emergence of large integrated firms in the United States. (Chandler 1997) It seems plausible that both in the case of Britain, the first industrializer, and Japan, the first non-Western country to create modern business enterprises, the identification of entrepreneurial opportunities, and the building of managerial structures which permitted their exploitation, may have been facilitated by geographically compact domestic markets and unusually large capital cities. 
The market opportunities for firms and entrepreneurs in most of Asia, Latin America and Africa were more constrained. They often faced great difficulties if they wanted to sell beyond their local markets because of poor transport and communications infrastructure. In India, market conditions have been identified as one explanation why India's powerful and rich merchants in the seventeenth and eighteenth centuries left manufacturing in the hands of small artisans, pointing to fragmented markets, inadequate transport infrastructure, and lawlessness (Tripathi, 2004) These constraints were relaxed as the British colonial regime promoted transport infrastructure, but a well-established argument in the literature on nineteenth century India has maintained that the small scale of the domestic market retarded the growth of a modern machinery industry. (Morris, 1983)

Yet it was often foreign firms, or ethnic minorities, which took advantage of expanding opportunities. Variations in entrepreneurial cognition may have been important. Most local entrepreneurs may not have been well-informed about the pace of change in advanced economies, and less knowledgeable about their markets, including the market for skilled expertise. A lack of English-speaking ability might have constrained access advanced knowledge in Latin America. The former imperial powers, Spain and Portugal, were in the backward south of Europe, and were not good role models of modern industrial growth.

As Casson has suggested, cultural differences towards information and "trust" levels may have been especially important in explaining variations in the quality of entrepreneurial judgments. (Casson 1991) It is evident that business enterprises in many non-Western societies were often challenged to grow beyond a certain size because their societies found it hard to "trust" non-family members as either managers or equity holders. 
Japan was an unusual society where "blood ties" were not decisive in determining trust levels. Arguably, the rapid Japanese move to employing professional managers may have reflected cultural traditions of adopting sons.

However many of the allegedly cultural explanations of why businesses in the Rest looked different to those in the West turn out to be misconceived. Much of the early literature on Latin American entrepreneurship in the nineteenth century blamed lack of economic growth on an alleged commercial and speculative ethos of the region's entrepreneurs. The family-owned diversified business groups which appeared during the nineteenth century in Latin America (and elsewhere) were regarded as inherently inefficient, and primarily vehicles for rent-seeking. However, such groups are now better understood as rational responses to weaknesses in capital markets, shortage of managerial resources, and high transactions costs. Within such conditions, business groups can, and often are, often the most effective forms of business organization. (Jones and Khanna, 2006)

Indeed, as entrepreneurs in the Rest began catching-up with their Western counterparts, they were often successful in developing hybrid organizational forms adapted to their local contexts. In China, the new modern business enterprises which appeared in early twentieth century typically combined the formal organization of Western-style corporations with traditional, well-established business practices from China's preindustrial past. A study of the rapid growth of Shanghai's print machinery industry from the late nineteenth century has shown that in this industry, unlike others such as textiles, Chinese entrepreneurs were so successful that they were able to replace foreign machine imports with products from the local machine industry. (Reed, 2004) 
The pre-eminence of ethnic and religious minorities in entrepreneurial activity points towards a combination of contextual explanations for the slow growth of modern business enterprise. As many countries in the Rest began to industrialize, minorities or immigrants were especially important in new firm creation. These included Chinese in south-east Asian, Indians in east Africa, Lebanese in West Africa, Italians in Argentina, and French in Mexico. Their success has often ascribed to particular ethical or working practices, but their role is more plausibly explained as a demonstration of the challenges faced by entrepreneurs in societies where trust levels were poor, information flows inadequate, institutions weak and capital scarcity. In such situations, small groups with shared values held major advantages as entrepreneurs. If in addition, they established an intermediary role between locals and Western firms, they could secure easier access to knowledge and information, from and about, Western countries.

The prominent roles of particular ethnic and religious groups in Indian modern industry can be explained in such terms. The role of the tiny Parsee community around Bombay has been variously described as the result of close relations with the colonial authorities, “outsider" minority status, and a "Protestant” style work ethic. (Desai 1968) However the Marwaris were far less close to the British. Indeed, a number of families, like the Bajaj, became active in the Independence struggle. Other explanations for their preeminence have been found in unique cost accounting methods and the work ethos. (Timburg, 1978)

Wolcott has combined both cultural and institutional factors to explain the preeminence of Indian minorities. She relates the situation to India's caste system, and argues that the payoffs to entrepreneurship differed across caste lines. Members of the 
moneylending and trading castes like the Marwaris could enforce contracts through reputation and membership deterred cheating. As a result, they were efficient at providing financial and other resources to entrepreneurs within their own castes. However, the large number of potential entrepreneurs outside these groups lacked privileged access to these informal financial networks, reducing their incentives to engage in productive entrepreneurship. (Wolcott, 2010)

The ethnic clustering in modern entrepreneurship in India, and elsewhere, was striking, but as Roy has suggested, another way to look at such clustering was geographically. Before 1914 Bombay and Calcutta accounted for half the modern factories in India, and even more of related services such as banking and insurance. Unlike other cities in India, they had grown through the activities of the East India Company, and were outward-oriented and cosmopolitan. In these two port cities, Roy observes, "modern Indian business enterprise and business families congregated and recreated a globalized world with strong Indian characteristics.” (Roy, 2012)

The emergence of hubs such as Bombay, and modern entrepreneurship in general, also took place within the context of the wider political economy environment. Explanations for why ethnic Chinese business became disproportionately important in Southeast Asia typically stress cultural factors, including the role of family, dialect groups and the Confucian value system. With respect to the latter, it has often been argued that social trust, the social obligations that bind family and lineage, was strengthened by the Confucian belief, and that provided the bedrock of commercial networking. Yet while some or all of these features may be significant, the growth of Chinese entrepreneurship in Southeast Asia also has to be placed within a wider political economy context. From the 
fourteenth century, the region's rulers favored foreign over local merchants because the latter might pose a political threat. Through the seventeenth century local trading communities, whether Malay or Filipino, continued to flourish, but the Chinese role was strengthened by the arrival of Western merchants, for the Chinese positioned themselves as intermediaries. By the late nineteenth century, the Chinese had secured the position of revenue farmers across the region, both in colonial and non-colonial areas. This made them indispensable for local and colonial governments, while providing a source of funds for their business interests. (Brown 2000)

It was also within the context of Western geo-political power that European and US firms surged abroad to the Rest looking for commodities and markets. By 1914 world FDI was not only substantial compared to world output, it was also primarily located in the non-Western world. Latin America and Asia were especially important as host regions, representing 33 and 21 per cent respectively of the total world stock of FDI. (Jones 2005; 23) If domestic entrepreneurship in the Rest struggled to get traction, it needs to be explained why foreign entrepreneurship did not exercise a more productive effect on local business systems.

The industrial composition of this FDI provides a partial answer. Possibly one half of total world FDI was invested in natural resources, and a further one-third in services, especially financing, insuring, transporting commodities and foodstuffs. Manufacturing FDI primarily went to serve the markets of the West, whilst most FDI in the Rest was either in resources or services.

Yet the establishment and maintenance of mines, oil fields, plantations, shipping depots, and railroad systems involved the transfer of packages of organizational and 
technological knowledge to host economies. Given the absence of appropriate infrastructure in developing countries, foreign enterprises frequently not only introduced technologies specific to their activities, but also social technologies such as police, postal and education systems. Between the late nineteenth century and 1914 residents of most of the world's cities were provided with access to electricity, in their homes or at work, or else in the form of street lighting. (Hausman et al, 2008)

However spillovers and linkages to local entrepreneurs were limited by the nature of global capitalism at the time. Many natural resource investments were enclavist. Minerals and agricultural commodities were exported with only the minimum of processing. Most value was added to the product in the developed economies. Foreign firms were large employers of labor at that time, but training was only provided to local employees to enable them to fill unskilled or semiskilled jobs. The nature of the industries and these employment practices meant that the diffusion of organizing and technological skills to developing economies was far less than to developed economies. Technological diffusion worked best when there were already established firms which could be stimulated to become more competitive by foreign firms, or had the capacity to absorb workers who moved on from foreign firms. (Jones 2014)

Nor were foreign companies typically transformers of domestic institutions. While theoretically they may have been channels to transfer aspects of the institutional arrangements in their home countries to their hosts, for the most part they reinforced local institutions. This was most directly seen in the concession system. In order to entice firms to make investments in mines, railroads, and so on, foreign firms were often given large concessions often involving freedom from taxation and other requirements over very long 
periods. (Jones 2005) Concessions worked to lock-in already sub-optimal institutional arrangements. In Mexico, President Diaz's contracts and concessions to the British engineering contractor Weetman Pearson was effective in securing major infrastructure improvements in railroads, ports and the drainage of Mexico City, and Pearson also laid the basis for the successful Mexican oil industry. Yet Pearson’s very success strengthened the autocratic and crony capitalist regime of Diaz. (Garner 2011)

The nature of the first global economy, then, meant that there was limited diffusion of entrepreneurship and organizing capabilities from Western firms in the Rest. Their primary impact was often to lock-in countries as resource providers, and to reinforce institutional constraints on domestic entrepreneurship rather than removing them. This partly explains why the domestic entrepreneurial response to globalization was weaker than might have been imagined, which at its heart lay in a lagged understanding of the opportunities offered by the new global economy combined with problems building effective business organizations which could absorb foreign technological and organizational skills. Public policy was one way to break constraints on local entrepreneurs, but few governments in developing countries had either the autonomy or the capacity to pursue effective public policies.

Yet by 1914 the evidence, patchy as it might be, suggests that the lag was being addressed in India, China, and some countries in Latin America, especially Argentina, where five large business groups had built diversified businesses spanning both manufacturing, finance and resources. (Barbero 2015, 8-14). During the interwar years there were significant examples of strong locally-owned business enterprises emerging in India, China, Egypt, Turkey and elsewhere. (Koll 2003, Zelin, 2005, Davis 1983, Colpan 
and Jones, 2016). However after World War 2, many governments opted for state-led industrialization programs which frequently disrupted local firms, whilst blocking or discouraging foreign firms. Protectionism and restrictions on foreign firms provided a context for new local firms to emerge, but these policies also provided incentives for firms to build skills in political contacts rather than technology. (Jones, 2013)

By 1980 the gap in income levels between the rich nations and the Rest was bigger than in 1914. Japan was the only case of a spectacular catch up, with a number of other smaller East and south-east Asian economies following at a distance. Elsewhere, state interventionist regimes had encountered growing problems of macro-economic instability and hyper-inflation by the 1970s. (Jones, 2013)

\section{The Great Convergence}

The fast economic growth seen in China and India, and certain other regions of the Rest also, from the 1980s provide limited support for North-style institutional arguments. China’s resurgence began under Deng Xiaoping, who had little concern with controls over the executive, human rights, political rights or intellectual property protection. There is more support for Baumol's argument that shifts in the rules of the game more broadly can stimulate productive entrepreneurship. Policy liberalization and deregulation important in allowing capitalist enterprise to flourish, even in Communist China.

Interestingly, many of the businesses which flourished with liberalization over the last thirty years had been founded and grew in the earlier era of import substitution. This policy regime provided local firms with opportunities to achieve scale within their protected domestic markets. A pioneer of this strategy was post-1945, which excluded most inward FDI, enabling automobile firms like Toyota and Nissan, and their electronics 
equivalents, to scale at home before seeking foreign markets. Two decades later it was in the context of a protected local market, and a repressive military regime, that South Korean chaebol such as Samsung got started. Similarly Cemex, now one of the world's largest cement companies, was founded in Mexico in 1906, and was able to grow in a sheltered environment slowly becoming a regional player and then, in the 1970s, a national player. As the Mexican and other economies liberalized, it was well-positioned to expand globally. In 1992, CEMEX began globalization by purchasing Spain's two largest cement companies.

In India, the era of the so-called "License Raj" between the 1950s and 1980s also enabled firms to grow within their domestic market. Arguably, it laid the basis for the country’s subsequently successful IT services sector. Postwar India had growing numbers of engineers owing to the many national institutes, engineering universities and regional colleges established after 1947. However, it had little choice to be totally dependent on US computer makers. During the 1960s and 1970s a handful of locally-owned firms were established to develop and run applications software for Indian companies and research institutions that had brought or leased mainframes from IBM and other US companies. Tata, which had remained India's largest business group, established the first of these firms, Tata Consulting Services in 1968. This and other ventures remained small, however, until 1977, when, after the Indian government tightened the laws on foreign ownership of firms, IBM and other US firms divested.

The departure of IBM opened new opportunities for local firms. TCS developed a relationship with another US computer maker, Burroughs, which provided an important channel of new technology. In 1982 the start-up Infosys was founded by the dynamic 
entrepreneur Narayana Murthy. The Indian firms built a strong trade association, NASSCOM, which sought to enhance and certify the quality of Indian firms. By the time policy regulation got underway in 1991, which gave Indian IT firms a freer hand in establishing marketing offices abroad and serving foreign clients, it had built strong organizational capabilities. The software industry became focused on Bangalore, where the British had established India’s first aircraft factory during World War 2, and which was the home of two of India's premier institutes of higher education in pure science. Like Silicon Valley, there was also a pleasant climate, at least before pollution began to increase. The government's establishment of a Software Technology Park, or export zone, in Bangalore in 1990, and an influx of expertise and contracts from the many expatriate Indians employed in Silicon Valley, were other influential factors in the growth of the Bangalore cluster. (Parthasarathy and Aoyama, 2006)

The liberalization of policies towards foreign firms was important too in the Great Convergence. China is a showcase for the transforming impact of global capitalism, as foreign firms played a key initial role in China's economic growth, and accounted for a high percentage of China’s exports. (Vogel, 2011) It is less evident that multinationals had a truly transformational effect on the Rest, even though almost everywhere policy regimes sought to attract them. In countries where export-oriented FDI was concentrated within free trade zones, linkages with local firms were particularly weak. (Jones 2014)

Nevertheless, certain aspects of global capitalism as it evolved from the 1980s delivered more opportunities for firms and entrepreneurs based in the Rest. An important development was the disintegration of the boundaries of M-form firms from the 1980s as many large Western corporations suffered from growing managerial diseconomies and low 
rates of innovation caused by size and diversification. The result was divestment of "noncore" businesses, outsourcing of many value-added activities, and the formation of alliances with other firms which acted as suppliers and customers, or as partners in innovation. While large Western corporations remained powerhouses of innovation spending and market power, they formed components of a worldwide web of inter-firm connections.

The disintegration of production systems and their replacement by networks of interfirm linkages lowered barriers for new entrants from the Rest. Within a network-type global economy, firms from emerging markets were able to piggy back on incumbent Western or Japanese firms as customers through subcontracting, linkages and leverages. (Mathews 2002) The spectacular growth of Taiwan's personal-computer industry from the 1980s, for example, was based on contract manufacturing for Western firms. However despite their technical capabilities, manufacturing prowess, and scale, most leading Taiwanese firms except Acer did not develop their own capabilities in branding and marketing. The nature of the relationship with established companies in the West, as well as local competition, seems to have constrained capability development among most firms. (Yu and Shih, 2014)

The Taiwanese electronics contract manufacturer Foxconn, founded by Terry Gou in 1974 (initially called Hon Hai) grew to be a \$140 billion company in 2017 with plants all over the world. A central driver of this growth was its role as the largest components supplier to Apple. Apple began outsourcing to Foxcomm in the late 1990s. Gou developed close relations with local government officials in China who provided cheap land and 
subsidies for plants to manufacture Apple products. When the iPhone was launched in 2007, Foxcomm secured agreement with the local government in Zhengzhou to subsidize the building of an industrial park located inside a bonded zone, with customs facilities at the factory gate to facilitate iPhone exports. The located government recruited and trained the manufacturing workforce which by 2016 amounted to 350,000 workers. Billions of dollars of financial incentives were provided by the local government also. (Barboza 2016) By then Foxcomm manufactured 90 per cent of Apple's iPhones. Foxcomm did not develop its own brands, but in 2016 it did acquire the troubled Japanese electronics company Sharp, which had an extensive branded consumer products business. By that year Foxcomm’s annual revenues had reached $\$ 140$ billion.

In some cases contractors created their own brands in time. The growth of Galanz was one example. Founded in 1978 by Liang Qingde as a company that dealt in the trading of duck feathers, Galanz began producing OEM Toshiba-branded microwave ovens in 1993. Galanz later purchased the appliance division from Toshiba. By the following decade Galanz had become the world's largest microwave manufacturer. (Mathews 2002)

If a major constraint for firms based in the Rest was not only the existence of entrepreneurial opportunities, but also the building of organizational capabilities to exploit them, then a number of developments during the second global economy alleviated this challenge, and facilitated "accelerated internationalization.” (Matthews and Zander 2007)

First, diaspora assumed a renewed importance as transferors of entrepreneurship and capital, and means by which firms could access management talent. The revitalized use of diaspora reflected changes in policies in China and India especially made them more 
attractive locations to do business, encouraging diaspora to return. After 1980, ethnic Chinese firms based in Hong Kong and Taiwan, and later elsewhere, became the leading foreign investors as China liberalized its economy. They enjoyed connections (guanxi) in China, which reduced the transactions costs of investment by offering contacts with public authorities and inside information, and were welcomed by the Chinese government. Many engineers settled in Silicon Valley and made up a quarter of the workforce by the 1990s. As the Indian economy grew from the 1990s, there has been a significant reverse flow back to India. This was assisted by the Indian government's new policy in 2003 of granting dual nationality to some overseas Indian residents abroad. These diaspora links provided valuable connections between Silicon Valley and Bangalore, encouraging business connections and capital flows. (Pandey 2004)

Secondly, both business schools and management consultants provided much easier access to new management knowledge, and they have played important roles in building organizational capabilities in firms. In postwar Europe both US management consultancies and business schools were influential diffusers of American managerial knowledge to Europe and other developed countries. The impact on emerging markets only became stronger later. McKinsey opened in India in 1992. From the 1980s leading US business schools have internationalized their faculty and student body.

Many of the most successful companies from the Rest used US consulting firms to provide advice on strategy, sent senior managers on executive programs at the top business schools, and recruited MBAs as graduates. None of this meant that such firms evolved as replicas of US firms, but it did mean that they had faster and better access to information about the latest managerial ideas in ways which were impossible fifty years ago. Cemex's 
global growth, for example, was led by a new generation of the founding Zambrano family. Lorenzo Zambrano, the architect of a new international strategy, had been educated at Stanford Business School, and sought strategy advice from Boston Consulting Group. (Lessard and Reavis, 2009)

A final, important, factor in the growth of global firms from some emerging markets was support from their host governments. The important role of governments in promoting catch-up echoed the model of the economic historian Alexander Gershenkron writing in the early 1960s who argued that governments would be important forces in countries seeking to catch-up from economic backwardness. (Gershenkron 1962). The spectacular growth of Gulf-based airlines such as Emirates and Qatar provided a prominent example, but it was in China were some of the spectacular results were seen. China was among the governments which used state-owned firms as national champions to pursue strategic objectives. (Child and Rodriques 2005). The growth of Chinese firms to dominate the global solar industry provided one such example. (Jones 2017: 342-345). A related category were highly politically connected firms such as HNA, which grew rapidly from the 2000s from its original business of Hainan Airlines, which included major investments in Western businesses such as Hilton and Deutsche Bank.(Weinland et al, 2017)

However while official blessing was key to growth for all Chinese global corporations, some corporations had less direct support from the government. This smaller category of firms were often founded by victims of the Cultural Revolution in their youths. They included Zong Qinhou and Wahaha), and Ren Zhengfei and Huawei. ${ }^{1}$ The spectacular growth of Huawei, the Chinese internet router company, was striking. Ren

\footnotetext{
${ }^{1}$ Email from Enlan Wang to Geoffrey Jones, June 262017.
} 
Zhengfei received credit from the state-owned development bank. Wireless networking was a strategic industry for the Chinese government, not least because the equipment was the hardware which enabled the government to censor information and monitor activity on the internet. However Huawei’s growth was not a simple story of growth based on political Gerscontacts and support. Ren Zhengfei implemented a clever strategy of building businesses in remoter and outlying cities in China before targeting the major cities where the American firm Cisco and others had built a market since the 1990s. He then repeated the strategy globally, first selling to countries like Russia, Brazil and Thailand, before moving to more advanced markets, especially in Europe. Huawei also invested heavily in research, creating research centers in numerous locations around the world including Bangalore and Silicon Valley. Innovation was supported by an aggressive corporate culture which rewarded talent. (Jones 2013)

The growth of powerful globally active corporations from the Rest, such as Huawei and Foxcomm and their equivalents in other countries, was a singular feature of contemporary global economy and a driver of the Great Convergence. Business historians have started to research how this happened, and there is much more to do.

\section{Conclusion}

This working paper has sought to integrate a business history perspective into debates about the Great Divergence and its consequences, and the more recent Great Convergence. While recognizing that the context of institutions, education and culture play a role in explanations of wealth and poverty, the working paper calls for a closer 
engagement with the processes how these factors translate into generating productive firms and entrepreneurs.

In explaining why the development of modern business enterprise in the Rest lagged, the recasting of existing literature into the framework of the Great Divergence debate permits important insights. The societal and cultural embeddedness of new technologies provide one important explanatory factor. Evidently, the challenges were sufficiently great in the Rest that minorities held significant advantages in capital-raising and trust levels which enabled them to flourish as entrepreneurs. They were also benefitted from a greater willingness to engage Western firms and colonial governments. In contrast, multinationals proved disappointing diffusers of organizational skills and information to the Rest, and had limited importance in relieving the institutional, human capital or other constraints faced by local entrepreneurs. By the interwar years there is evidence of emergent modern entrepreneurship and business enterprise in Asia, Latin America and Africa. However many governmental policies after 1945 designed to facilitate catch-up ended up crippling such emergent business enterprises without putting an effective alternatives in place.

The second wave of globalization from the 1980s, which is now ending, provided more opportunities for catch up from the Rest. Firms from emerging markets had the opportunity to access the global networks which in part replaced large integrated firms. There were also new ways for firms in the Rest to access knowledge and capital. Business historians have an enormous opportunity to contribute to understanding these processes. 


\section{Acknowledgements}

I would like to thank Christina Lubinski and participants of a workshop in Glasgow, Scotland on June 292017 for helpful comments on an earlier draft of this working paper. Enlan Wang generously provided crucial insights on the typology of Chinese firms in recent decades.

\section{References}

R.C. Allen, Jean-Pascal Bassino, Debin Ma, Christine Moll-Murata and Jan Luiten van Zanden (2011), “Wages, Prices, and Living Standards in China, Japan, and Europe, 17381925,” Economic History Review 64, (1), 2011, 8-38.

M.I. Barbero, “Business groups in nineteenth and twentieth century Argentina,” IN: G. Jones and A. Lluch, eds, The Impact of Globalization on Argentina and Chile. Business Enterprises and Entrepreneurship. Northampton, MA: Edward Elgar, 2015.

D. Barboza, “How China Built ‘iPhone City’ with billions in perks for Apple’s Partner,” New York Times, December 292016.

W. J. Baumol, “Entrepreneurship: Productive, Unproductive, and Destructive,” Journal of Political Economy, 98, (5), 1990, 893-921.

E Beatty, “Approaches to technology transfer in History and the Case of Nineteenth Century Mexico,” Comparative Technology Transfer and Society, 1, (2), 2003a, 167-200.

Idem, “Bottles for Beer: The Business of Technological Innovation in Mexico, 1890-1920,” Business History Review, 83, 2003b, 317-348.

A.Bénétrix, K. O’Rourke \& J. Williamson (2015). "The Spread of Manufacturing to the Poor Periphery 1870-2007," Open Economies Review, 26(1) 2015, 1-37. 
S. Broadberry, "Accounting for the Great Divergence," London School of Economics, Economic History Working Papers, 184 (November 2013)

S. Broadberry, and B. Gupta (2006),”The early modern great divergence: wages, prices and economic development in Europe and Asia, 1500-1800”, Economic History Review 59, (1) 2006, 2-31

R.A. Brown, Chinese Big Business and the Wealth of Asian Nations, London: Palgrave, 2000.

M. Casson, The Economics of Business Culture, Oxford: Clarendon Press, 1991.

M. Cerutti, “Estudios regionals e historia empresarial en Mexico (1840-1920): Una revision de lo producido desde 1975,” In: C. Davilla, ed. Empresa e historia en América Latina, Bogota: Tercer Mundo/Colciendas, 1996.

A.D. Chandler, The Visible Hand, Cambridge, MA: Harvard University Press, 1977.

J. Child and S.B. Rodriques, "The internationalization of Chinese firms: A case for theoretical extension?” Management and Organization Review, 1, (3) 2005, 381-418.

A. Colli and M Rose, “Family Capitalism” In Jones and Zeitlin (eds.) Oxford Handbook, pp. 194-218.

A. Colpan and G. Jones, "Business Groups, Entrepreneurship and the Growth of the Koç Group in Turkey," Business History 58, (1), 2016, 69-88.

E. Davis, Challenging colonialism: Bank Miṣr and Egyptian industrialization, 1920-1941 Princeton, N.J: Princeton University Press, 1983.

J-L Duanmu, "Firm heterogeneity and location choice of Chinese multinational enterprises," Journal of World Business, 47, (1), 2012, 64-72.

K. Deng, "A Critical Survey of Recent Research in Chinese Economic History," Economic History Review, LIII, (1) 2000, 1-28. 
K. Deng and P. O'Brien, "How well did facts travel to support protracted debate on the history of the Great Divergence between Western Europe and Imperial China,” MPRA Paper No. 77276, March 52017.

A. Desai, “The Origins of Parsi entrepreneurship," Indian Economic and Social History Review, 5, (4) 1968, 307-18;

R. A. Easterlin, “Why Isn't the Whole World Developed?” The Journal of Economic History, 41 (1), 1981,1-19.

S L. Engerman with E, Mariscal, "The Evolution of Schooling, 1800-1925," IN S.L. Engerman, and K. I. Sokoloff, Economic Development in the Americas since 1500 New York: Cambridge University Press, 2012, 121-167.

D. Faure, China and Capitalism, Hong Kong: Hong Kong University Press, 2006.

N. Ferguson, Civilization. The West and the Rest, London: Allen Lane 2011.

N. Foss and T. Pedersen, "Transferring Knowledge in MNCs: The Roles of Sources of Subsidiary Knowledge and Organizational Context,” Journal of International Management 8, 2002, 1-19.

P. Garner, British Lions and Mexican Eagles Business, Politics, and Empire in the Career of Weetman Pearson in Mexico, 1889-1919, Stanford: Stanford University Press, 2011.

A. Gershenkron, Economic Backwardness in Historical Perspective, Cambridge, MA: Harvard University Press, 1962.

C. Goldin, “The Human-Capital Century and American Leadership” Journal of Economic History, 61 (2), 2001, 263-91. 
W.J. Hausman, P. Hertner, and M. Wilkins, (eds.) Global Electrification. MNE Enterprise and International Finance in the History of Light and Power 1878-2007, Cambridge: Cambridge University Press, 2008.

G. Jones, Multinationals and Global Capitalism, Oxford: Oxford University Press, 2005.

Idem, Entrepreneurship and Multinationals. Global Business and the Making of the Modern World, Northampton, MA: Edward Elgar, 2013.

Idem, Profits and Sustainability. A History of Green Entrepreneurship, Oxford: Oxford University Press, 2017.

Idem, "Business History and the Impact of MNEs on Host Economies," Research in Global Strategic Management, 16, 2014, 177-198.

Idem and T. Khanna, "Bringing History (Back) into International Business," Journal of International Business Studies 37, (4), 2006, 453-468.

Idem and R.D. Wadhwani, “Entrepreneurship,” In G. Jones and J. Zeitlin, eds, The Oxford Handbook of Business History. Oxford: Oxford University Press, 2008, 501-528.

W. C. Kirby, "China Unincorporated: Company Law and Business Enterprise in TwentiethCentury China,” Journal of Asian Studies, 54, (1) 1995, $43-63$.

E. Koll, From Cotton Mill to Business Empire, Cambridge, MA: Harvard University Press, 2003.

D. S. Landes, The Wealth and Poverty of Nations, New York; W.W. Norton, 1998.

B.Li and J. L. van Zanden , "Before the Great Divergence? Comparing the Yangzi Delta and the Netherlands at the Beginning of the Nineteenth Century," Journal of Economic History, 72, (4), 2012, 956-989.

C.D. R. Lessard and C. Reavis, "CEMEX: Globalization “The Cemex Way,” 
MITSloan Management Case, 09-039, March 2009.

C. Markovits, Merchants, traders, entrepreneurs: Indian business in the colonial era, New York: Palgrave Macmillan, 2008.

J.A. Mathews, Dragon Multinational. A New Model for Global Growth, Oxford: Oxford University Press, 2002.

J. A Matthews and I. Zander, "The international entrepreneurial dynamics of accelerated internationalization,” Journal of International Business Studies, 38, 2007, pp. 387-403.

M.D. Morris, “The Growth of Large-Scale Industry to 1947,” in Dharma Kumar, ed., The Cambridge Economic History of India, Cambridge: Cambridge University Press, 1983.

N. Maurer, The Power and the Money. The Mexican Financial System, 1876-1932, Stanford: Stanford University Press, 2002.

J. Mokyr, The Lever of Riches, Oxford: Oxford University Press, 1990.

J. Mokyr, "Intellectual Property Rights, the Industrial Revolution, and the beginnings of modern economic growth," American Economic Review Papers and Proceedings, 99 (2) (2009), 349-355;

P. Moser, "Patents and Innovation: Evidence from Economic History," Journal of Economic Perspectives, 27(1), (2013), 23-44.

A. Musacchio, "Can Civil Law Countries get Good Credit Institutions? Lessons from the History of Creditor Rights and Bond Markets in Brazil," Journal of Economic History, 68, (1) 2008, 80-108.

D.C. North, Institutions, Institutional Change and Economic Performance, Cambridge: Cambridge University Press, 1990. 
Idem, Understanding the Process of Economic Change, Princeton: Princeton University Press, 2005.

U. Olsson, "Securing the markets. Swedish Multinationals in a historical perspective," In: G. Jones and H. G. Schröter, eds., The Rise of Multinationals in Continental Europe (Aldershot: Edward Elgar, 1993), 100-102.

B. Parthasarathy and Y. Aoyama, "From software services to R\&D services: local entrepreneurship in the software industry in Bangalore, India," Environment and Planning A, 38, 2006, $1269-1285$.

A. Pandey, A. Aggarwal, R. Devane, and Y. Kuznetsov, "India's Transformation to Knowledge-Based Economy - Evolving Role of the Indian Diaspora,” Evalueserve (July 2004). Accessed at http://info.worldbank.org/etools/docs/library/152386/abhishek.pdf.

K. Pomeranz (2000). The Great Divergence (Princeton: Princeton University Press, 2000).

C. A. Reed, Gutenberg in Shanghai. Chinese Print Capitalism 1876-1937 (Honolulu: University of Hawaii Press, 2004);

T. Roy, "Beyond Divergence: Rethinking the Economic History of India,” Economic History of Developing Regions, 27, (1) 2012.

T. Roy, "Did Globalization Aid Industrial Development in Colonial India? A Study of Knowledge Transfer in the Iron Industry,” Indian Economic and Social History Review, 46, 4, 2009, 579-613.

T. Roy, The Economic History of India 1857-1947. New Delhi: Oxford University Press, 2000.

T. A Timburg, The Marwaris, from traders to industrialists, New Delhi: Vikas, 1978.

D. Tripathi, Oxford History of Indian Business, New Dehli: Oxford University Press, 2004. 
E. F. Vogel, Deng Xiaoping and the transformation of China (Cambridge, MA: Belknap Press, 2011).

M. Weber, The Protestant Ethic and the Spirit of Capitalism, Oxford: Oxford University Press, 2011 ed.

D. Weinland, A. Massoudi and J. Fontanella-Khan, HNA’s buying spree surpasses \$40bn with CWT deal," Financial Times, April 92017

H. Yu and W. C. Shih, “Taiwan's PC Industry, 1976-2010: The Evolution of Organizational Capabilities,” Business History Review, 88 (2), 2014, 329 - 357.

World Economic Forum (2017) https://www.weforum.org/agenda/2017/03/worlds-biggesteconomies-in-2017.

J. L. van Zanden, “The Skill Premium and the 'Great Divergence,”” European Review of Economic History, 13, 2009, 121-153.

1. Zan and K. Deng, "Micro Foundations in the Great Divergence Debate: Opening up a New Perspective,” London School of Economics, Economic History Working Papers, No 256 (January 2017).

M. Zelin, The Merchants of Zigong (New York: Columbia University Press, 2005);

S Wolcott, "An examination of the Supply of Financial Credit to Entrepreneurs in Colonial India,” IN: Landes et al, Invention, 443-468. 